\title{
Neutrale
}

\section{Unternehmensbewertung juristische Personen}

\section{$8 \%$}

